\title{
Animal Models of Generalized Dystonia
}

\author{
Robert S. Raike,* H. A. Jinnah,* and Ellen J. Hess** \\ ${ }^{*}$ Departments of Neurology and ${ }^{\dagger}$ Neuroscience, Johns Hopkins University School of Medicine, Baltimore, Maryland 21287
}

\begin{abstract}
Summary: Dystonia is a prevalent neurological disorder characterized by abnormal co-contractions of antagonistic muscle groups that produce twisting movements and abnormal postures. The disorder may be inherited, arise sporadically, or result from brain insult. Dystonia is a heterogeneous disorder because patients may exhibit focal or generalized symptoms associated with abnormalities in many brain regions including basal ganglia and cerebellum. Elucidating the pathogenic mechanisms underlying dystonia has therefore been challenging. Animal models of dystonia exhibit similar heterogeneity and are useful for understanding pathogenesis. The neurochemical and neurophysiological abnormalities in rodents with id-
\end{abstract}

iopathic generalized dystonia suggest that dysfunctional output from basal ganglia, cerebellum, or from multiple systems is the cause of motor dysfunction. Findings from drug- or toxininduced dystonia in rodents and nonhuman primates mirror the genetic models. The parallels between dystonia in humans and animals suggest that the models will continue to prove useful in determining pathogenesis. Furthermore, detailed characterization of the existing models of dystonia and the development of new models hold promise for the identification of novel therapeutics. Key Words: Basal ganglia, striatum, cerebellum, inferior olive, mice, rat.
Dystonia is the third most common movement disorder behind essential tremor and Parkinson disease. Dystonia is characterized by involuntary twisting movements and abnormal postures, which are caused by simultaneous contractions of opposing muscle groups. Dystonia can be classified in terms of etiology; it may be inherited or arise sporadically (primary cases), or follow brain trauma or insult (secondary cases). However, it is estimated that approximately two thirds of all dystonia cases are not associated with identifiable pathology and are therefore deemed idiopathic. Dystonia may also be classified by the distribution of affected muscle groups. Focal or segmental forms of the disorder involve a small number of muscles, such as those of the hand in writer's cramp or of the neck in torticollis. In contrast, generalized dystonia, the focus of this review, is characterized by involvement of muscles throughout the body as observed in DYT1 (early onset torsion) dystonia. The etiological and phenotypic diversity of disorders classified as dystonia underscores its heterogeneity.

Movement disorders are often attributed to dysfunction of the basal ganglia (e.g., chorea and bradykinesia)

Address correspondence and reprint requests to Ellen J. Hess, Ph.D., Department of Neurology Johns Hopkins University School of Medicine, 600 North Wolfe Street, Meyer 6-181, Baltimore, MD 21287. E-mail: ehess@jhmi.edu. or the cerebellum (e.g., ataxia and tremor). In particular, dystonia has traditionally been considered to be a disorder of the basal ganglia because patients with secondary dystonia commonly exhibit lesions within basal ganglia structures, including caudate, putamen, globus pallidus, and thalamus ${ }^{1}$; functional imaging demonstrates that these types of lesions are associated with metabolic abnormalities within basal ganglia and premotor cortex. Further, DOPA-responsive dystonia almost certainly results from basal ganglia dysfunction. ${ }^{2-4}$ However, substantial evidence also implicates cerebellar dysfunction in cases of both primary and secondary dystonia. Several studies reveal hypermetabolic signals within premotor cortex and cerebellum associated with primary dystonias, such as hemidystonia, exercise-induced paroxysmal dystonia, and DYT1 dystonia. ${ }^{4-7}$ Moreover, patients with secondary cervical dystonia most commonly exhibit lesions within cerebellum or its afferents. ${ }^{8}$ Thus, these clinicopathologic correlations suggest dysfunction of the basal ganglia, cerebellum, or both regions as potential sources of dystonia in humans.

Animal models are essential to investigate the neurobiological basis of disease pathogenesis because idiopathic dystonias are functional disorders. Several models of generalized dystonia exist, including those exhibiting dysfunction of the basal ganglia, cerebellum, or both systems. Dystonia in animals may result from inherited 
mutations (primary) or be experimentally introduced (secondary). Hence, animal models of dystonia exhibit a heterogeneity that parallels the human disorder. Given the inherent limits associated with conducting experiments in patients, spontaneous and derived animal models are valuable tools for discerning the neuroanatomical, biochemical, and physiological basis of dystonia, and for testing potential therapeutics.

\section{ANIMAL MODELS IMPLICATING BASAL GANGLIA DYSFUNCTION}

\section{The $d t^{s z}$ hamster}

Motor dysfunction. The $d t^{s z}$ motor disorder was identified within an inbred line of Syrian hamsters and originally described as a recessively inherited epileptic disorder. ${ }^{9}$ However, further analysis of the $d t^{s z}$ hamster phenotype reveals that it bears a close resemblance to generalized paroxysmal dystonia in humans; stress-induced $d t^{s z}$ hamster attacks of dystonia can last for hours and vary in severity, progressing from the head to the extremities. ${ }^{10,11}$ Generally, attacks begin with ear flattening and facial contortions, followed by stiffening of the hind limbs, gait abnormalities and frequent falling, and culminating with limb hyperextension and severe truncal torsion and flexion. ${ }^{10}$

Attacks in $d t^{s z}$ hamsters are age dependent because they are observable after the second week, peak in severity between the fourth and sixth week, and disappear sometime after the eighth week of life. ${ }^{12}$ Although $d t^{s z}$ hamsters lose the susceptibility to attack during pubescence, male or female gonadectomy does not preclude remission. ${ }^{13}$ In fact, the $d t^{s z}$ phenotype is not entirely transient because late-term pregnant and nursing female $d t^{s z}$ hamsters may exhibit the dystonic attacks. ${ }^{9,13}$ Thus, dystonia in adult $d t^{s z}$ hamsters is likely modified but not determined by hormonal fluctuations.

Neuropathology. Upon gross histological examination, the $d t^{s z}$ hamster brain appears relatively normal. ${ }^{14}$ However, a reduction in parvalbumin immunoreactivity is observed throughout the $d t^{z z}$ hamster striatum, suggesting a marked deficit in the number of GABAergic interneurons and implicating the basal ganglia as the source of dystonic attacks. ${ }^{15}$

Pharmacological findings further support the notion of aberrant basal ganglia GABAergic neurotransmission as a factor in the $d t^{s z}$ hamster disease pathogenesis. Systemic administration or intrastriatal injection of agents that increase GABAergic transmission either ameliorate or block $d t^{s z}$ attacks. ${ }^{10,16,17}$ In contrast, systemic or local application of GABA receptor antagonists worsens the dystonia. ${ }^{10,16,17}$ The improvement observed with drugs that promote GABA release likely occurs by offsetting the significant deficit of GABAergic striatal interneurons, which predicts disinhibition of striatal efferents. ${ }^{15}$
These defects in GABAergic regulation within the striatum suggest the $d t^{s z}$ disorder may be pathogenically related to some forms of idiopathic paroxysmal dyskinesia in humans because dystonia in mutant hamsters and patients responds to similar pharmacological treatments, such as systemic administration of benzodiazepines. ${ }^{10,17,18}$

Mutant hamsters also exhibit abnormal striatal dopamine regulation. Although interictal levels are normal, attacks of dystonia are associated with transient but significant increases in striatal dopamine overflow. ${ }^{19}$ Furthermore, intrastriatal coadministration of D1 and D2 dopamine receptor antagonists prevents $d t^{s z}$ attacks, suggesting that increased dopamine overflow is necessary for the expression of dystonic symptoms. ${ }^{20}$

Pathophysiology. The $d t^{s z}$ hamster basal ganglia exhibit several neurophysiological abnormalities. Baseline EEG recordings from asymptomatic animals reveal highly irregular patterns of electrical activity within caudate, putamen, and globus pallidus. ${ }^{21}$ Furthermore, field and single unit recordings of evoked and spontaneous activity within the $d t^{s z}$ striatum suggest these irregularities may stem from significant increases in corticostriatal and striatopallidal excitability. ${ }^{22,23}$ These abnormalities appear to have profound effects within the entopeduncular nucleus, which is the equivalent of the internal segment of the globus pallidus in humans. In the absence of dystonic attacks, recordings of single unit activity demonstrate significant reductions in spontaneous discharge rate and irregular burst morphology within the $d t^{s z}$ entopeduncular nucleus, suggesting physiological abnormalities observed within striatum result in increased entopeduncular inhibition. ${ }^{15,24}$ Interestingly, entopeduncular physiological abnormalities are age dependent and are detectable only in attack-prone animals. ${ }^{12,24}$ Thus, the aberrant neurophysiological activity detected within the $d t^{s z}$ basal ganglia point to dysfunctional output from the entopeduncolothalamic pathway in the generation of dystonia.

\section{Dystonia induced by 3-nitropropionic acid}

Clinical studies. Several outbreaks of noninflammatory encephalopathy have occurred in humans as a result of ingesting moldy sugarcane. The contaminant, arthrinium fungus, produces 3-nitropropionic acid (3-NPA), a potent neurotoxin that interferes with mitochondrial respiration. ${ }^{25}$ Although acute 3-NPA poisoning is characterized by severe gastrointestinal distress, CNS symptoms such as convulsions or coma commonly follow. ${ }^{26}$ Shortly after consciousness is regained, up to $25 \%$ of adolescent patients develop segmental or generalized dystonia, which may be chronic or paroxysmal. ${ }^{26,27}$

Although the distribution and character of dystonia varies between patients, cranial imaging reveals a common neuropathology: acquired lesions of the basal ganglia. In particular, computed tomography scan and magnetic resonance imaging (MRI) demonstrate that cases of 
secondary dystonia after 3-NPA ingestion are associated with consistent bilateral hypodensity within striatum and globus pallidus. ${ }^{26,27}$ Subsequently, 3-NPA was administered to nonhuman species to establish an inducible model for dystonia.

Experimental studies. Peripheral administration of 3-NPA to rodents results in nearly selective lesions of striatum, ${ }^{25,28,29}$ and is associated with a motor disorder that closely resembles 3-NPA toxicity in humans. In mouse and rat, delayed onset dystonia is characterized by truncal and limb dystonia, the severity of which correlates with the size of striatal lesions. ${ }^{29,30}$ Furthermore, as in humans, the response of rats to 3-NPA toxicity is age dependent, whereby younger animals are more susceptible to acquiring the dystonia. ${ }^{25}$

Nonhuman primates also exhibit late-onset dystonia after administration of 3-NPA. Dystonic movements begin several weeks after cessation of 3-NPA treatment and generally progress until symptoms become generalized. ${ }^{31,32}$ Here again, MRI indicates the dystonia is associated with lesions of caudate and putamen after either subacute or chronic doses. ${ }^{31-33}$ Moreover, as noted in humans and rodents, the severity of dystonia observed in nonhuman primates is consistent with the degree of striatal damage induced by 3 -NPA toxicity. ${ }^{31}$

Histological examination of striatal damage induced by 3-NPA in both rodents and nonhuman primates indicates a major loss of striatal projection neurons, ${ }^{25,29,33}$ coupled with increases in striatal dopamine, suggesting a reduction in striatonigral inhibition. ${ }^{34}$ Thus, 3-NPA-induced striatal lesions predict dysfunctional basal ganglia output is the cause of dystonia.

\section{Dystonia induced by chronic dopamine therapy}

Nonhuman primate studies. Parkinson's disease (PD) is a progressive neurodegenerative disorder characterized by a selective loss of striatal dopaminergic innervation from substantia nigra. Patients with PD often exhibit tremor, bradykinesia, and shuffled gait. In humans and nonhuman primates, the mitochondrial complex II inhibitor with 1-methyl-4-phenyl-1,2,3,6-tetrahydropyridine (MPTP) produces selective lesions of dopamine-containing cells within the substantia nigra, replicating the symptoms of PD. ${ }^{35-37}$ Consequently, the MPTP-treated nonhuman primate is the most commonly used primate model of PD.

Dopamine replacement therapy through chronic administration of the dopamine precursor levodopa (LDOPA) or of dopamine receptor agonists remains the most effective treatment for PD. However, long-term dopamine replacement in PD has major drawbacks because dyskinesia with features of dystonia is a common side effect in both PD patients and MPTP-treated nonhuman primates, and 6-OHDA-treated rodents. ${ }^{38-43}$ Dyskinesia with dystonia also occurs in healthy nonhu- man primates following chronic L-DOPA administration alone. ${ }^{44}$ In all cases, the severity of dyskinesia correlates with the amount of striatal damage preceding treatment as well as duration and intensity of drug administration. ${ }^{39,40,44}$ Functional imaging and metabolic mapping studies suggest dyskinesia after chronic dopamine replacement therapy is associated with abnormal activity within basal ganglia, resulting in dysfunctional thalamocortical input. ${ }^{45-47}$

\section{Comment on basal ganglia dysfunction in dystonia}

Animal models of generalized dystonia implicating dysfunctional basal ganglia output are associated with significant pathology within striatum. The $d t^{s z}$ basal ganglia exhibit widespread electrophysiological abnormalities, possibly due to deficits in striatal GABAergic transmission, predicting decreased output from the entopeduncolothalamic pathway. However, the physiological evidence from studies of human dystonia is not as clear. Whereas pallidal discharge rates are reduced in patients with dystonia, suggesting that neostriatal activity is increased, ${ }^{48-51}$ dual recordings of globus pallidus and putamen in dystonic patients do not support this conclusion because a reduction in discharge rates is observed in both structures. ${ }^{48}$

The dystonia associated with 3-NPA toxicity and with long-term dopamine replacement therapy in animal models and patients suggests a role for this neurotransmitter in the disorder. Whereas dystonia in $d t^{s z}$ hamsters and 3-NPA treated animals is associated with a significant increase in striatal dopamine overflow, striatal dopamine deficiency can also result in dystonia as observed in DOPA-responsive dystonia. ${ }^{20,52-54}$ Although the exact pathogenic mechanisms are not clear, primary and secondary pathological defects in basal ganglia output likely result in aberrant thalamocortical input and disorganized motor processing.

\section{ANIMAL MODELS IMPLICATING CEREBELLAR DYSFUNCTION}

\section{The $d t$ rat}

Motor dysfunction. The recessively inherited $d t$ rat motor disorder was first observed within a colony of Sprague Dawley breeders. ${ }^{55,56}$ Whereas motor dysfunction is undetectable in neonates, $d t$ rats develop generalized dystonia approximately 10 days after birth, with twisting movements of the neck, paddling motions of the limbs and postural instability. ${ }^{55,56}$ After onset of the $d t$ motor phenotype, symptom severity and distribution progress rapidly; $d t$ rats display fore- and hindlimb selfclasping, truncal flexion, and sustained axial twisting movements (FIG. 1A) ${ }^{55,56}$ As in human generalized dystonia, motor dysfunction occurs only in waking $d t$ rats and subsides during rest. ${ }^{55}$ 

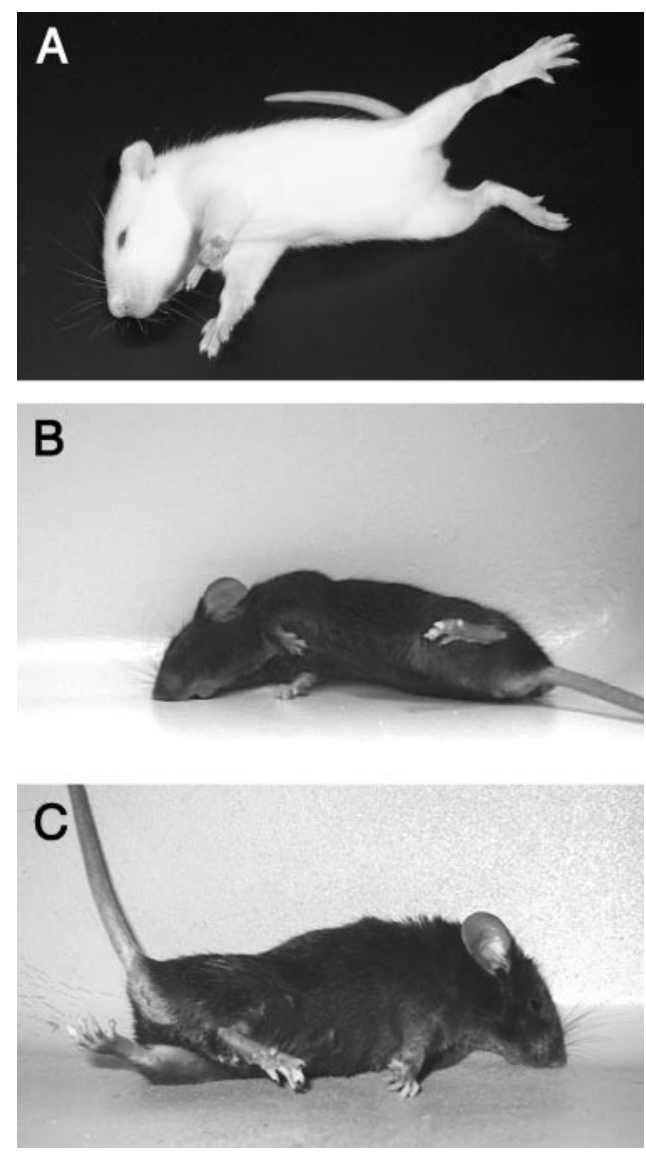

FIG. 1. Typical dystonic postures observed in $d t$ rats (A), tottering mice (B), and kainate-induced dystonia (C).

Neuropathology. Despite the early onset of severe symptoms, no obvious gross neuroanatomical abnormalities are apparent except for an overall reduction in $d t$ rat brain mass. ${ }^{55}$ This reduction, which is observed in older dystonic animals, is likely due to feeding deficits rather than a degenerative process, ${ }^{55}$ because histological examination of striatum, cerebellum, and deep cerebellar nuclei reveals no significant evidence of cells loss within the $d t$ rat brain. ${ }^{55,57-59}$ However, cytological studies demonstrate that Purkinje cell soma are significantly smaller in $d t$ rat brain, implicating the cerebellum in the motor phenotype. ${ }^{58,60}$

Although abnormal metabolic activity is detected throughout the $d t$ rat motor system, including striatum, ${ }^{61}$ there is little evidence to suggest that the basal ganglia are specifically affected. ${ }^{55,57,62}$ However, several neurochemical abnormalities are observed within cerebellum. First, the concentration of norepinephrine is significantly increased within the $d t$ rat cerebellum ${ }^{55}$ but does not likely factor in the dystonia. ${ }^{58,63}$ Next, both GABA synthesis and concentration are significantly elevated in $d t$ rat Purkinje cells, but not in basal ganglia. ${ }^{64-66}$ In contrast, cells of the deep cerebellar nuclei (DCN), where Purkinje cell axons terminate, exhibit a substantial re- duction in GAD activity and GABA receptor density. ${ }^{62,65}$ Because the development of the GABAergic abnormalities parallels the progression of the disease, ${ }^{64,67}$ and because diazepam provides relief, ${ }^{55,64}$ GABAergic dysregulation likely contributes to the expression of the dystonia.

The biochemical perturbations observed within $d t$ rat cerebellum may result from abnormal Purkinje cell innervation by climbing afferents from the inferior olive (IO). Dystonic rats are insensitive to the tremorogenic effects of harmaline, which potentiates climbing fiber input. ${ }^{60}$ In contrast, $d t$ rats are hypersensitive to tremorogenic effects induced by the serotonergic agonist quipazine, which also stimulates IO activity. ${ }^{68}$ Serotonergic regulation appears normal elsewhere in $d t$ rat brain, ${ }^{62,63}$ suggesting defects specific to the olivocerebellar pathway are associated with the dystonia.

Pathophysiology. The olivocerbellar network is also the site of neurophysiological irregularities including abnormal spontaneous activity from the $d t$ rat IO, Purkinje cell layer, and DCN. ${ }^{59,69,70}$ Single unit recordings from $d t$ rat Purkinje neurons reveal a reduced rate of complex spiking and abnormal patterns of simple spike bursting. ${ }^{71}$ In addition, the increase in complex spike activity normally observed in response to harmaline is absent in $d t$ rat Purkinje cells,${ }^{60,71}$ which is consistent with the failure of harmaline to induce tremor in these animals. Neurons within the $d t$ rat lateral and interpositus DCN display increased rhythmic bursting, with the most severe alterations in patterned activity detected in older animals with advanced dystonia. ${ }^{72}$ Hyperpolarizing current injections or artificial stimulation of Purkinje cell input exerts similar effects in preparations from normal brain, ${ }^{73}$ suggesting that rhythmic bursting within the $d t$ rat DCN is a consequence of aberrant Purkinje cell input. Taken together, the data implicate defective climbing fiber innervation of Purkinje cells and predict dysfunctional output from cerebellum. Perhaps the most compelling evidence for the involvement of the cerebellum is that either removal of the cerebellum or lesions of the DCN alleviate symptoms in $d t$ rats, indicating cerebellar output is necessary for dystonia. ${ }^{74,75}$

\section{The Cav 2.1 calcium channel mouse mutants}

Human and mouse mutations. $\mathrm{Ca}_{\mathrm{v}} 2.1$ (P/Q-type) calcium channels regulate neurotransmitter release and neuronal firing patterns throughout the brain. However, these voltage-gated channels are expressed abundantly within Purkinje cells of the cerebellum, where they are located presynaptically on axon terminals ${ }^{76}$ and postsynaptically on dendrites and soma. ${ }^{77}$ Several human neurological diseases characterized by cerebellar dysfunction including episodic ataxia type 2 , familial hemiplegic migraine, and spinocerebellar ataxia type 6 , result from mutations within the CACNA1A gene, ${ }^{78,79}$ which en- 
codes the pore-forming $\alpha_{1} 2.1$ subunit of $\mathrm{Ca}_{\mathrm{v}} 2.1$ calcium channels. In addition to the signs for which each disorder was named, patients may also suffer from dystonia. ${ }^{80-86}$ Mice bearing mutations within the Cacnala gene are models of dystonia arising from cerebellar dysfunction; dystonia is a prominent feature of the tottering ${ }^{87}$ and leaner (as observed by authors) mouse motor phenotypes. Both Cacnala mutations associated with the tottering and leaner motor disorders, Cacnala ${ }^{\text {tg }}$ and Cacnala $a^{\text {tg-la }}$, arose spontaneously and result in abnormal $\mathrm{Ca}_{\mathrm{v}} 2.1$ calcium channel function. ${ }^{88-90}$ Moreover, mice carrying targeted disruptions of Cacnala, which eliminate $\mathrm{Ca}_{\mathrm{v}} 2.1$ currents entirely, also exhibit a motor disorder reminiscent of generalized dystonia in humans. ${ }^{91,92}$

Motor dysfunction. Tottering is a recessively inherited motor disorder where mice experience highly stereotyped paroxysmal episodes of motor dysfunction, which last 20-60 min and are precipitated by stress, caffeine, and ethanol. ${ }^{93}$ Attacks in tottering mice usually begin with hindlimb posturing, then spread and become generalized to include truncal and neck flexion, forelimb posturing and facial contortion (FIG. 1B). ${ }^{93-95}$ At the most advanced stages of attack, tottering mice typically assume prolonged twisting postures involving the entire body, including the ears, eyes and jaw. ${ }^{93,94}$ Between attacks, tottering exhibit a mild, but noticeable ataxia. Although the tottering mouse phenotype was initially described as a motor seizure disorder, ${ }^{96}$ no epileptiform activity is associated with the motor dysfunction, ${ }^{95,96}$ and the sustained and asynchronous movements observed during attacks more closely resemble those of paroxysmal dystonia in humans.

The motor disorders of leaner mice and the $\mathrm{Ca}_{\mathrm{v}} 2.1$ null mutants are recessively inherited and are chronic. Beginning approximately $2-3$ weeks after birth, progressive and debilitating dystonia develops, which in weanlings causes death indirectly by inhibiting feeding. ${ }^{91,92,97,98}$ Whereas the leaner disorder was originally classified as an ataxic disorder, dystonic extension of the limbs on one side of the body actually causes these mice to lean and ultimately fall (as observed by authors). Furthermore, the motor dysfunction in leaner is widespread with involvement of the tongue and jaw muscles, suggesting that it is a model of generalized dystonia rather than ataxia. The $\mathrm{Ca}_{\mathrm{v}} 2.1$ null mutant phenotype is very similar to the leaner mouse, but more severe.

Neuropathology. Although neuronal degeneration is not observed in tottering mice, ${ }^{94,96}$ total cerebellar volume is significantly less than in wild-type mice. ${ }^{99} \mathrm{~A}$ reduction in Purkinje cell size may account for the atrophic tottering mouse cerebellum; abnormalities in dendritic and axonal morphology also suggest altered connectivity within cerebellar circuitry. ${ }^{98-100}$ In contrast, widespread cerebellar atrophy occurs in leaner mice and the $\mathrm{Ca}_{\mathrm{v}} 2.1$ null mutants with progressive degeneration of granule, golgi, and Purkinje neurons. ${ }^{91,92,101,102}$ In fact, by 1 year of age, only about $20 \%$ of the original population of Purkinje cells remains in leaner mice. ${ }^{102}$ Additionally, Purkinje cells in both tottering and leaner mice exhibit ectopic expression of tyrosine hydroxylase ${ }^{103-105}$ that is likely due to an increase in $\mathrm{Ca}_{\mathrm{v}} 1.2$ (L-type) channel expression resulting from the reduction in $\mathrm{Ca}_{\mathrm{v}} 2.1$ activity. ${ }^{106}$ In general, the neuropathology observed in these mice points to dysfunctional Purkinje cells without obvious striatal dysfunction.

Pathophysiology. Tottering mouse Purkinje cells exhibit an approximate $40 \%$ reduction in $\mathrm{Ca}_{\mathrm{v}} 2.1$ calcium current density. ${ }^{88}$ The reduced $\mathrm{Ca}_{\mathrm{v}} 2.1$ current density in tottering triggers compensatory mechanisms to maintain calcium homeostasis, such as the upregulation of $\mathrm{Ca}_{\mathrm{v}} 1.2$ channels. ${ }^{87}$ Indeed, these secondary effects may contribute to the dystonia because blockers of $\mathrm{Ca}_{\mathrm{v}} 1.2$ activity prevent dystonic attacks in tottering mice, whereas the $\mathrm{Ca}_{\mathrm{v}} 1.2$ channel activator Bay K8644 induces stereotypic episodes in tottering mice. ${ }^{87}$ Additionally, an apparent shift to reliance on $\mathrm{Ca}_{\mathrm{v}} 2.2$ (N-type) channels for neurotransmission ${ }^{107,108}$ may underlie the reduced electrical coupling between granule and Purkinje cells synapses and the increased sensitivity to modulation by $\mathrm{G}$ proteins detected in tottering cerebellum. ${ }^{109,110}$

The reduction and absence of $\mathrm{Ca}_{\mathrm{v}} 2.1$ currents in leaner mice and the null mutants, respectively, ${ }^{89-92,105}$ also trigger compensatory changes in calcium handling. In mice without $\mathrm{Ca}_{\mathrm{v}} 2.1$ currents, increased expression of both $\mathrm{Ca}_{\mathrm{v}} 1.2$ and $\mathrm{Ca}_{\mathrm{v}} 2.2$ channels is observed. ${ }^{91,92}$ Furthermore, studies of leaner Purkinje cells demonstrate that diminished $\mathrm{Ca}_{\mathrm{v}} 2.1$ activity is associated with decreased expression of calcium-binding proteins, lessening the ability to properly buffer intracellular calcium. ${ }^{111}$

Whereas mouse mutants with reduced or abolished $\mathrm{Ca}_{\mathrm{v}} 2.1$ currents exhibit significant cerebellar pathophysiology, the exact mechanisms of dystonia are not clear. In tottering mice, dystonia is associated with activation c-fos expression within the entire olivocerebellar network and its efferent targets, but not within basal ganglia. ${ }^{12}$ Moreover, genetic, chemical or surgical lesions that partially or completely eliminate cerebellar output alleviate dystonic attacks in tottering mice, ${ }^{113,114}$ suggesting that the cerebellum is necessary for the expression of dystonia.

\section{Dystonia induced by kainate}

Microinjection studies. Low-dose microinjections of the glutamate receptor agonist kainate into the cerebellar vermis induce dystonia in normal mice. ${ }^{115}$ Approximately 10-20 min after injection, abnormal movements begin with the hindlimbs, but shortly thereafter symptoms become more generalized to include the trunk and forelimbs (FIG. 1C). Similar to dystonia in tottering, kainate-induced dystonia in normal mice is associated 
with increased c-fos expression within cerebellum. ${ }^{12,115}$ Only cerebellar injection of glutamatergic agonists but not antagonists results in dystonia, clearly demonstrating involvement of kainate or AMPA receptor activation ${ }^{115}$ Microinjection of kainate into basal ganglia does not induce motor dysfunction, nor does it induce dystonia when injected into the cerebella of mice lacking Purkinje cells, indicating that output from cerebellum is necessary for expression of the dystonia. ${ }^{115}$

\section{Comment on cerebellar dysfunction in dystonia}

Models of idiopathic and secondary generalized dystonia in mouse and rat implicate the cerebellum in this movement disorder. Dystonia is a movement disorder characterized by disrupted timing and coordination of antagonistic muscle contractions, and one that has been traditionally viewed as being associated with dysfunctional basal ganglia output. Neurological disorders originating from cerebellum, such as ataxia, are normally associated with loss of function. However, evidence from clinical studies implicates abnormal cerebellar activity in dystonia, which can be viewed as a gain of function lesion similar to epilepsy in the cerebral cortex. Along with the expected metabolic increases in the caudate, lentiform nuclei, and supplementary motor areas, positron emission tomography (PET) detects hypermetabolism within the cerebella of patients suffering from DYT1, an early-onset idiopathic torsion dystonia. ${ }^{16,117}$ Similarly, in acquired hemisdystonia, which affects one side of the body, PET reveals hypermetabolism within ipsilateral cerebellum and several contralateral cortical motor areas. ${ }^{4}$ Moreover, patients with exercise-induced paroxysmal dystonia exhibit increased cerebellar perfusion and reduced cortical and basal ganglia perfusion during motor attacks. ${ }^{118}$ Taken together, findings from animal and clinical studies demonstrate that dysfunctional cerebellar output is sufficient for the expression of generalized dystonia.

\section{SUMMARY AND CONCLUSIONS}

Dystonia is a prevalent movement disorder in humans, generally characterized by the simultaneous contraction of opposing muscle groups. The circumstances of dystonia are variable, manifesting in paroxysmal or chronic symptoms with focal or generalized patterns of distribution. Whereas initial clinical studies implicated pathology within basal ganglia as the principal source of idiopathic and acquired dystonias, substantial evidence identifies cerebellar dysfunction as another common cause of the disorder.

Clearly, the heterogeneity exhibited by human dystonia is represented in animal models of the disorder. Several demonstrate that dysfunctional output from the basal ganglia can result in dystonia. In these models, abnormal nigrostriatal dopaminergic neurotransmission ${ }^{19,20,39,40,44}$ accompanied by neurophysiological irregularities predict disorganized thalamocortical signaling that may drive the dystonia. ${ }^{22,24,119}$ In contrast, the models of dystonia implicating the cerebellum predict abnormal cerebellar signaling, including Purkinje cells and deep cerebellar nuclei, with involvement of the entire olivocerebellar system. ${ }^{56,59,115}$ Moreover, selectively eliminating cerebellar output in these cases blocks the dystonia. ${ }^{74,75,113,114}$ Considering that both systems serve to modulate movement, the notion that simultaneous dysfunction of basal ganglia and cerebellum may be involved in different manifestations of dystonia is not unreasonable.

However, it is unlikely that the pathogenesis in all dystonias is simply due to either basal ganglia or cerebellar dysfunction. Dystonia may be associated with neuronal dysfunction that is widespread. Dystonia musculorum is a mouse motor disease resembling generalized dystonia in humans. The disorder results from mutations of the Bpagl gene, which encodes a protein important in the cytoskeletal organization of all neurons. ${ }^{120,121}$ As a consequence, mice with dystonia musculorum exhibit lesions within several brain regions, including basal ganglia, cerebellum and sensory neurons. ${ }^{122,123}$ The dystonia evoked by $\mathrm{Ca}_{\mathrm{v}} 1.2$ (L-type) calcium channel activation also implicates widespread neuronal dysfunction. In normal animals, administration of Bay K 8644 or FPL 64179, both L-type calcium channel agonists, induces generalized dystonia that is associated with extensive neuronal activation throughout brain, including striatum, cerebellum, hippocampus, and cortex. ${ }^{124,125}$ Elucidating the pathophysiology that ultimately generates the dystonia in such models may be particularly challenging.

The evidence emerging from both clinical and animal studies demonstrates that dystonia may be associated with dysfunction of broad networks or with defects in the basic components of motor control. Moreover, animal models clearly support the idea that dystonia may involve pathology within single or multiple motor pathways. Given the clinical heterogeneity of the disorder, these implications are not surprising. That the animal models of dystonia mirror the human findings is promising, but the complexity of the disorder in both cases suggests that a single defining mechanism of pathogenesis is unlikely. The development of therapeutics may therefore necessitate novel strategies targeting broad categories of dystonia. Animal models of dystonia hold potential for such an approach whereby therapeutics effective in several different models will provide strong evidence for clinical efficacy.

Acknowledgments: We thank Dr. Mark S. LeDoux for the photograph of the $d t$ rat. This work was supported by United 
States Public Health Service Grants R01 NS33592 and R01 NS40470.

\section{REFERENCES}

1. Marsden CD, Obeso JA, Zarranz JJ. The anatomical basis of symptomatic dystonia. Brain 108:463-483, 1985.

2. Galardi G, Perani D, Grassi F, Bressi S, Amadio S, Antoni M, et al. Basal ganglia and thalamo-cortical hypermetabolism in patients with spasmodic torticollis. Acta Neurol Scand 94:172-176, 1996.

3. Karbe H, Holthoff VA, Rudolf J, Herholz K, Heiss WD. Positron emission tomography demonstrates frontal cortex and basal ganglia hypometabolism in dystonia. Neurology 42:1540-1544, 1992.

4. Ceballos-Baumann AO, Passingham RE, Marsden CD, Brooks DJ. Motor reorganization in acquired hemidystonia. Ann Neurol 37:746-757, 1995.

5. Odergren T, Stone-Elander S, Ingvar M. Cerebral and cerebellar activation in correlation to the action-induced dystonia in writer's cramp. Mov Disord 13:497-508, 1998.

6. Preibisch C, Berg D, Hofmann E, Solymosi L, Naumann M. Cerebral activation patterns in patients with writer's cramp: a functional magnetic resonance imaging study. J Neurol 248:10 17, 2001.

7. Hutchinson M, Nakamura T, Moeller JR, Antonini A, Belakhlef A, Dhawan V, et al. The metabolic topography of essential blepharospasm: a focal dystonia with general implications. Neurology 55:673-677, 2000.

8. LeDoux MS, Brady KA. Secondary cervical dystonia associated with structural lesions of the central nervous system. Mov Disord 18:60-69, 2003.

9. Yoon $\mathrm{CH}$, Peterson JS, Corrow D. Spontaneous seizures: a new mutation in Syrian golden hamsters. J Hered 67:115-116, 1976.

10. Loscher W, Fisher JE Jr, Schmidt D, Fredow G, Honack D, Iturrian WB. The sz mutant hamster: a genetic model of epilepsy or of paroxysmal dystonia? Mov Disord 4:219-232, 1989.

11. Bhatia KP. Familial (idiopathic) paroxysmal dyskinesias: an update. Semin Neurol 21:69-74, 2001.

12. Richter A, Loscher W. Alterations in pharmacological sensitivity of GABAergic but not dopaminergic and glutamatergic systems during ontogenesis in dystonic mutant hamsters. Eur J Pharmacol 231:111-119, 1993.

13. Loscher W, Blanke T, Richter A, Hoppen HO. Gonadal sex hormones and dystonia: experimental studies in genetically dystonic hamsters. Mov Disord 10:92-102, 1995.

14. Wahnschaffe U, Fredow G, Heintz P, Loscher W. Neuropathological studies in a mutant hamster model of paroxysmal dystonia. Mov Disord 5:286-293, 1990.

15. Gernert M, Hamann M, Bennay M, Loscher W, Richter A. Deficit of striatal parvalbumin-reactive GABAergic interneurons and decreased basal ganglia output in a genetic rodent model of idiopathic paroxysmal dystonia. J Neurosci 20:7052-7058, 2000.

16. Fredow G, Loscher W. Effects of pharmacological manipulation of GABAergic neurotransmission in a new mutant hamster model of paroxysmal dystonia. Eur J Pharmacol 192:207-219, 1991.

17. Hamann M, Richter A. Effects of striatal injections of GABA(A) receptor agonists and antagonists in a genetic animal model of paroxysmal dystonia. Eur J Pharmacol 443:59-70, 2002.

18. Demirkiran M, Jankovic J. Paroxysmal dyskinesias: clinical features and classification. Ann Neurol 38:571-579, 1995.

19. Hamann M, Richter A. Striatal increase of extracellular dopamine levels during dystonic episodes in a genetic model of paroxysmal dyskinesia. Neurobiol Dis 16:78-84, 2004.

20. Rehders JH, Loscher W, Richter A. Evidence for striatal dopaminergic overactivity in paroxysmal dystonia indicated by microinjections in a genetic rodent model. Neuroscience 97:267-277, 2000.

21. Gernert M, Richter A, Rundfeldt C, Loscher W. Quantitative EEG analysis of depth electrode recordings from several brain regions of mutant hamsters with paroxysmal dystonia discloses frequency changes in the basal ganglia. Mov Disord 13:509-521, 1998.
22. Gernert M, Richter A, Loscher W. Alterations in spontaneous single unit activity of striatal subdivisions during ontogenesis in mutant dystonic hamsters. Brain Res 821:277-285, 1999.

23. Kohling R, Koch UR, Hamann M, Richter A. Increased excitability in cortico-striatal synaptic pathway in a model of paroxysmal dystonia. Neurobiol Dis 16:236-245, 2004.

24. Gernert M, Bennay M, Fedrowitz M, Rehders JH, Richter A Altered discharge pattern of basal ganglia output neurons in an animal model of idiopathic dystonia. J Neurosci 22:7244-7253, 2002.

25. Beal MF, Brouillet E, Jenkins BG, Ferrante RJ, Kowall NW, Miller JM, et al. Neurochemical and histologic characterization of striatal excitotoxic lesions produced by the mitochondrial toxin 3-nitropropionic acid. J Neurosci 13:4181-4192, 1993.

26. He F, Zhang S, Qian F, Zhang C. Delayed dystonia with striatal CT lucencies induced by a mycotoxin (3-nitropropionic acid). Neurology 45:2178-2183, 1995.

27. Ming L. Moldy sugarcane poisoning - a case report with a brief review. J Toxicol Clin Toxicol 33:363-367, 1995.

28. Fu Y, He F, Zhang S, Jiao X. Consistent striatal damage in rats induced by 3-nitropropionic acid and cultures of arthrinium fungus. Neurotoxicol Teratol 17:413-418, 1995.

29. Fernagut PO, Diguet E, Stefanova N, Biran M, Wenning GK, Canioni $\mathrm{P}$, et al. Subacute systemic 3-nitropropionic acid intoxication induces a distinct motor disorder in adult C57B1/6 mice: behavioural and histopathological characterisation. Neuroscience 114:1005-1017, 2002.

30. Ouary S, Bizat N, Altairac S, Menetrat H, Mittoux V, Conde F, et al. Major strain differences in response to chronic systemic administration of the mitochondrial toxin 3-nitropropionic acid in rats: implications for neuroprotection studies. Neuroscience 97: 521-530, 2000.

31. Palfi S, Leventhal L, Goetz CG, Hantraye T, Roitberg B, Sramek $\mathrm{J}$, et al. Delayed onset of progressive dystonia following subacute 3-nitropropionic acid treatment in Cebus apella monkeys. Mov Disord 15:524-530, 2000.

32. Ghorayeb I, Fernagut PO, Stefanova N, Wenning GK, Bioulac B, Tison F. Dystonia is predictive of subsequent altered dopaminergic responsiveness in a chronic 1-methyl-4-phenyl-1,2,3,6-tetrahydropyridine +3-nitropropionic acid model of striatonigral degeneration in monkeys. Neurosci Lett 335:34-38, 2002.

33. Brouillet E, Hantraye P, Ferrante RJ, Dolan R, Leroy-Willig A, Kowall NW, et al. Chronic mitochondrial energy impairment produces selective striatal degeneration and abnormal choreiform movements in primates. Proc Natl Acad Sci USA 92:7105-7109, 1995.

34. Johnson JR, Robinson BL, Ali SF, Binienda Z. Dopamine toxicity following long term exposure to low doses of 3-nitropropionic acid (3-NPA) in rats. Toxicol Lett 116:113-118, 2000.

35. Langston JW, Ballard P, Tetrud JW, Irwin I. Chronic parkinsonism in humans due to a product of meperidine-analog synthesis. Science 219:979-980, 1983.

36. Przedborski S, Jackson-Lewis V. Mechanisms of MPTP toxicity. Mov Disord 13:35-38, 1998.

37. Burns RS, Chiueh CC, Markey SP, Ebert MH, Jacobowitz DM, Kopin IJ. A primate model of parkinsonism: selective destruction of dopaminergic neurons in the pars compacta of the substantia nigra by N-methyl-4-phenyl-1,2,3,6-tetrahydropyridine. Proc Natl Acad Sci USA 80:4546-4550, 1983.

38. Rascol O, Brooks DJ, Korczyn AD, De Deyn PP, Clarke CE, Lang AE. A five-year study of the incidence of dyskinesia in patients with early Parkinson's disease who were treated with ropinirole or levodopa. 056 Study Group. N Engl J Med 342: 1484-1491, 2000.

39. Pearce RK, Jackson M, Smith L, Jenner P, Marsden CD. Chronic L-DOPA administration induces dyskinesias in the 1-methyl-4phenyl-1,2,3,6-tetrahydropyridine-treated common marmoset (Callithrix jacchus). Mov Disord 10:731-740, 1995.

40. Clarke CE, Sambrook MA, Mitchell IJ, Crossman AR. Levodopainduced dyskinesia and response fluctuations in primates rendered parkinsonian with 1-methyl-4-phenyl-1,2,3,6-tetrahydropyridine (MPTP). J Neurol Sci 78:273-280, 1987.

41. Boyce S, Clarke CE, Luquin R, Peggs D, Robertson RG, Mitchell 
$\mathrm{IJ}$, et al. Induction of chorea and dystonia in parkinsonian primates. Mov Disord 5:3-7, 1990.

42. Winkler C, Kirik D, Bjorklund A, Cenci MA. L-DOPA-induced dyskinesia in the intrastriatal 6-hydroxydopamine model of Parkinson's disease: relation to motor and cellular parameters of nigrostriatal function. Neurobiol Dis 10:165-186, 2002.

43. Lundblad M, Picconi B, Lindgren H, Cenci MA. A model of L-DOPA-induced dyskinesia in 6-hydroxydopamine lesioned mice: relation to motor and cellular parameters of nigrostriatal function. Neurobiol Dis 16:110-123, 2004.

44. Pearce RK, Heikkila M, Linden IB, Jenner P. L-dopa induces dyskinesia in normal monkeys: behavioural and pharmacokinetic observations. Psychopharmacology (Berl) 156:402-409, 2001.

45. Mitchell IJ, Luquin R, Boyce S, Clarke CE, Robertson RG, Sambrook MA, et al. Neural mechanisms of dystonia: evidence from a 2-deoxyglucose uptake study in a primate model of dopamine agonist-induced dystonia. Mov Disord 5:49-54, 1990.

46. Brooks DJ. PET studies and motor complications in Parkinson's disease. Trends Neurosci 23:S101-S108, 2000.

47. Brooks DJ, Piccini P, Turjanski N, Samuel M. Neuroimaging of dyskinesia. Ann Neurol 47:S158-S159, 2000.

48. Sanghera MK, Grossman RG, Kalhorn CG, Hamilton WJ, Ondo WG, Jankovic J. Basal ganglia neuronal discharge in primary and secondary dystonia in patients undergoing pallidotomy. Neurosurgery 52:1358-1370; discussion 1370-1353, 2003.

49. Starr PA, Rau GM, Davis V, Marks WJ, Ostrem JL, Simmons D, et al. Spontaneous pallidal neuronal activity in human dystonia: comparison with Parkinson's disease and normal macaque. J Neurophysiol 10.1152/jn.00971.2004, 9 Feb 2005.

50. Zhuang P, Li Y, Hallett M. Neuronal activity in the basal ganglia and thalamus in patients with dystonia. Clin Neurophysiol 115: 2542-2557, 2004.

51. Vitek JL, Chockkan V, Zhang JY, Kaneoke Y, Evatt M, DeLong MR, et al. Neuronal activity in the basal ganglia in patients with generalized dystonia and hemiballismus. Ann Neurol 46:22-35, 1999.

52. Brautigam C, Wevers RA, Jansen RJ, Smeitink JA, de Rijk-van Andel JF, Gabreels FJ, et al. Biochemical hallmarks of tyrosine hydroxylase deficiency. Clin Chem 44:1897-1904, 1998.

53. Hyland K, Surtees RA, Rodeck C, Clayton PT. Aromatic L-amino acid decarboxylase deficiency: clinical features, diagnosis, and treatment of a new inborn error of neurotransmitter amine synthesis. Neurology 42:1980-1988, 1992.

54. Ichinose H, Ohye T, Takahashi E, Seki N, Hori T, Segawa M, et al. Hereditary progressive dystonia with marked diurnal fluctuation caused by mutations in the GTP cyclohydrolase I gene. Nat Genet 8:236-242, 1994.

55. Lorden JF, McKeon TW, Baker HJ, Cox N, Walkley SU. Characterization of the rat mutant dystonic (dt): a new animal model of dystonia musculorum deformans. J Neurosci 4:1925-1932, 1984.

56. Lorden JF, Oltmans GA, Stratton S, Mays LE. Neuropharmacological correlates of the motor syndrome of the genetically dystonic (dt) rat. Adv Neurol 50:277-297, 1988.

57. McKeon TW, Lorden JF, Oltmans GA, Beales M, Walkley SU. Decreased catalepsy response to haloperidol in the genetically dystonic (dt) rat. Brain Res 308:89-96, 1984.

58. McKeon TW, Lorden JF, Beales M, Oltmans GA. Alterations in the noradrenergic projection to the cerebellum of the dystonic (dt) rat. Brain Res 366:89-97, 1986.

59. Lorden JF, Lutes J, Michela VL, Ervin J. Abnormal cerebellar output in rats with an inherited movement disorder. Exp Neurol 118:95-104, 1992.

60. Lorden JF, Oltmans GA, McKeon TW, Lutes J, Beales M. Decreased cerebellar $3^{\prime}, 5^{\prime}$-cyclic guanosine monophosphate levels and insensitivity to harmaline in the genetically dystonic rat (dt). J Neurosci 5:2618-2625, 1985.

61. Brown LL, Lorden JF. Regional cerebral glucose utilization reveals widespread abnormalities in the motor system of the rat mutant dystonic. $J$ Neurosci 9:4033-4041, 1989.

62. Beales M, Lorden JF, Walz E, Oltmans GA. Quantitative autoradiography reveals selective changes in cerebellar GABA receptors of the rat mutant dystonic. J Neurosci 10:1874-1885, 1990.
63. LeDoux MS, Lorden JF, Ervin JM. Inferior olive serotonin and norepinephrine levels during development in the genetically dystonic rat. Brain Res Bull 33:299-305, 1994.

64. Oltmans GA, Beales M, Lorden JF, Gordon JH. Alterations in cerebellar glutamic acid decarboxylase (GAD) activity in a genetic model of torsion dystonia (rat). Exp Neurol 85:216-222, 1984.

65. Naudon L, Delfs JM, Clavel N, Lorden JF, Chesselet MF. Differential expression of glutamate decarboxylase messenger RNA in cerebellar Purkinje cells and deep cerebellar nuclei of the genetically dystonic rat. Neuroscience 82:1087-1094, 1998.

66. Lutes J, Lorden JF, Davis BJ, Oltmans GA. GABA levels and GAD immunoreactivity in the deep cerebellar nuclei of rats with altered olivo-cerebellar function. Brain Res Bull 29:329-336, 1992.

67. Oltmans GA, Beales M, Lorden JF. Glutamic acid decarboxylase activity in micropunches of the deep cerebellar nuclei of the genetically dystonic (dt) rat. Brain Res 385:148-151, 1986.

68. Michela VL, Stratton SE, Lorden JF. Enhanced sensitivity to quipazine in the genetically dystonic rat (dt). Pharmacol Biochem Behav 37:129-133, 1990.

69. Stratton SE, Lorden JF. Effect of harmaline on cells of the inferior olive in the absence of tremor: differential response of genetically dystonic and harmaline-tolerant rats. Neuroscience 21:543-549, 1991.

70. Stratton SE, Lorden JF, Mays LE, Oltmans GA. Spontaneous and harmaline-stimulated Purkinje cell activity in rats with a genetic movement disorder. J Neurosci 8:3327-3336, 1988.

71. LeDoux MS, Lorden JF. Abnormal spontaneous and harmalinestimulated Purkinje cell activity in the awake genetically dystonic rat. Exp Brain Res 145:457-467, 2002.

72. LeDoux MS, Hurst DC, Lorden JF. Single-unit activity of cerebellar nuclear cells in the awake genetically dystonic rat. Neuroscience 86:533-545, 1998.

73. Llinas R, Muhlethaler M. Electrophysiology of guinea-pig cerebellar nuclear cells in the in vitro brain stem-cerebellar preparation. J Physiol (Lond) 404:241-258, 1988.

74. LeDoux MS, Lorden JF, Meinzen-Derr J. Selective elimination of cerebellar output in the genetically dystonic rat. Brain Res 697: 91-103, 1995.

75. LeDoux MS, Lorden JF, Ervin JM. Cerebellectomy eliminates the motor syndrome of the genetically dystonic rat. Exp Neurol 120: 302-310, 1993.

76. Westenbroek RE, Sakurai T, Elliott EM, Hell JW, Starr TV, Snutch TP, et al. Immunochemical identification and subcellular distribution of the $\alpha 1 \mathrm{~A}$ subunits of brain calcium channels. J Neurosci 15:6403-6418, 1995.

77. Usowicz MM, Sugimori M, Cherksey B, Llinas R. P-type calcium channels in the somata and dendrites of adult cerebellar Purkinje cells. Neuron 9:1185-1199, 1992.

78. Zhuchenko O, Bailey J, Bonnen P, Ashizawa T, Stockton DW, Amos C, et al. Autosomal dominant cerebellar ataxia (SCA6) associated with small polyglutamine expansions in the $\alpha 1 \mathrm{~A}$ voltage-dependent calcium channel. Nat Genet 15:62-69, 1997.

79. Ophoff RA, Terwindt GM, Vergouwe MN, van Eijk R, Oefner PJ, Hoffman SM, et al. Familial hemiplegic migraine and episodic ataxia type- 2 are caused by mutations in the $\mathrm{Ca} 2+$ channel gene CACNL1A4. Cell 87:543-552, 1996.

80. Lee WY, Jin DK, Oh MR, Lee JE, Song SM, Lee EA, et al. Frequency analysis and clinical characterization of spinocerebellar ataxia types 1, 2, 3, 6, and 7 in Korean patients. Arch Neurol 60:858-863, 2003.

81. Ikeuchi T, Takano H, Koide R, Horikawa Y, Honma Y, Onishi Y, et al. Spinocerebellar ataxia type 6: CAG repeat expansion in $\alpha 1 \mathrm{~A}$ voltage-dependent calcium channel gene and clinical variations in Japanese population. Ann Neurol 42:879-884, 1997.

82. Sethi KD, Jankovic J Dystonia in spinocerebellar ataxia type 6 . Mov Disord 17:150-153, 2001.

83. Jen J, Kim GW, Baloh RW. Clinical spectrum of episodic ataxia type 2. Neurology 62:17-22, 2004.

84. Giffin NJ, Benton S, Goadsby PJ. Benign paroxysmal torticollis of infancy: four new cases and linkage to CACNA1A mutation. Dev Med Child Neurol 44:490-493, 2002. 
85. Arpa J, Cuesta A, Cruz-Martinez A, Santiago S, Sarria J, Palau F. Clinical features and genetic analysis of a Spanish family with spinocerebellar ataxia 6. Acta Neurol Scand 99:43-47, 1999.

86. Spacey SD, Materek LA, Szczygielski BI, Bird TD. Two novel CACNA1A gene mutations associated with episodic ataxia type 2 and interictal dystonia. Arch Neurol 62:314-316, 2005.

87. Campbell DB, Hess EJ. L-type calcium channels contribute to the tottering mouse dystonic episodes. Mol Pharmacol 55:23-31, 1999.

88. Wakamori M, Yamazaki K, Matsunodaira H. Single tottering mutations responsible for the neuropathic phenotype of the P-type calcium channel. J Biol Chem 273:34857-34867, 1998.

89. Dove LS, Abbott LC, Griffith WH. Whole-cell and single-channel analysis of p-type calcium currents in cerebellar Purkinje cells of leaner mutant mice. J Neurosci 18:7687-7699, 1998.

90. Lorenzon NM, Lutz CM, Frankel WN, Beam KG. Altered calcium channel currents in Purkinje cells of the neurological mutant mouse leaner. J Neurosci 18:4482-4489, 1998.

91. Jun K, Piedras-Renteria ES, Smith SM, Wheeler DB, Beom SB, Lee TG, et al. Ablation of P/Q-type $\mathrm{Ca} 2+$ channel currents, altered synaptic transmission, and progressive ataxia in mice lacking the $\alpha 1$ a subunit. Proc Natl Acad Sci USA 96:1524515250, 1999.

92. Fletcher CF, Tottene A, Lennon VA, Wilson SM, Dubel SJ, Paylor R, et al. Dystonia and cerebellar atrophy in Cacna1a null mice lacking P/Q calcium channel activity. FASEB J 15:12881290, 2001.

93. Fureman BE, Jinnah HA, Hess EJ. Triggers of paroxysmal dyskinesia in the calcium channel mouse mutant tottering. Pharmacol Biochem Behav 73:631-637, 2002.

94. Green MC, Sidman RL. Tottering-a neuromuscular mutation in the mouse. J Hered 53:233-237, 1962.

95. Kaplan BJ, Seyfried TN, Glaser GH. Spontaneous polyspike discharges in an epileptic mutant mouse (tottering). Exp Neurol 66:577-586, 1979.

96. Noebels JL, Sidman RL. Inherited epilepsy: spike-wave and focal motor seizures in the mutant mouse tottering. Science 204:13341336, 1979.

97. Yoon CH. Disturbances in the developmental pathways leading to a neurological disorder of genetic origin, "leaner," in mice. Dev Biol 20:158-181, 1969.

98. Meier H, MacPike AD. Three syndromes produced by two mutant genes in the mouse. Clinical, pathological, and ultrastructural bases of tottering, leaner, and heterozygous mice. J Hered 62: 297-302, 1971.

99. Isaacs KR, Abbott LC. Cerebellar volume decreases in the tottering mouse are specific to the molecular layer. Brain Res Bull 36:309-314, 1995.

100. Rhyu IJ, Abbott LC, Walker DB, Sotelo C. An ultrastructural study of granule cell/Purkinje cell synapses in tottering $(\mathrm{tg} / \mathrm{tg})$, leaner $(\operatorname{tg}(\mathrm{la}) / \operatorname{tg}(\mathrm{la}))$ and compound heterozygous tottering/leaner $(\operatorname{tg} / \operatorname{tg}(\mathrm{la}))$ mice. Neuroscience 90:7-28, 1999.

101. Heckroth JA, Abbott LC. Purkinje cell loss from alternating sagittal zones in the cerebellum of leaner mutant mice. Brain Res 658:93-104, 1994.

102. Herrup K, Wilczynski SL. Cerebellar cell degeneration in the leaner mutant mouse. Neuroscience 7:2185-2196, 1982.

103. Abbott LC, Isaacs KR, Heckroth JA. Co-localization of tyrosine hydroxylase and zebrin II immunoreactivities in Purkinje cells of the mutant mice, tottering and tottering/leaner. Neuroscience 71: 461-475, 1996.

104. Hess EJ, Wilson MC. Tottering and leaner mutations perturb transient developmental expression of tyrosine hydroxylase in embryologically distinct Purkinje cells. Neuron 1:123-132, 1991.

105. Fletcher CF, Lutz CM, O'Sullivan TN, Shaughnessy JD, Hawkes R, Frankel WN, et al. Absence epilepsy in tottering mutant mice is associated with calcium channel defects. Cell 87:607-617, 1996.

106. Fureman BE, Campbell DB, Hess EJ. Regulation of tyrosine hydroxylase expression in tottering mouse Purkinje cells. Neurotox Res 5:521-528, 2003.

107. Quian J, Noebels JL. Presynaptic $\mathrm{Ca}(2+)$ influx at a mouse central synapse with $\mathrm{Ca}(2+)$ channel subunit mutations. $J$ Neurosci 20:163-170, 2000.

108. Ayata C, Shimizu-Sasamata M, Lo EH, Noebels JL, Moskowitz MA. Impaired neurotransmitter release and elevated threshold for cortical spreading depression in mice with mutations in the $\alpha 1 \mathrm{~A}$ subunit of P/Q type calcium channels. Neuroscience 95:639-645, 2000.

109. Zhou YD, Turner TJ, Dunlap K. Enhanced G protein-dependent modulation of excitatory synaptic transmission in the cerebellum of the $\mathrm{Ca} 2+$ channel-mutant mouse, tottering. J Physiol (Lond) 547:496-507, 2003.

110. Matsushita K, Wakamori M, I.J R, Arii T, Oda S, Mori Y, et al. Bidirectional alterations in cerebellar synaptic transmission of tottering and rolling $\mathrm{Ca} 2+$ channel mutant mice. J Neurosci 22:4388-4398, 2002.

111. Dove LS, Nahm SS, Murchison D, Abbott LC, Griffith WH. Altered calcium homeostasis in cerebellar Purkinje cells of leaner mutant mice. J Neurophysiol 84:513-524, 2000.

112. Campbell DB, Hess EJ. Cerebellar circuitry is activated during convulsive episodes in the tottering (tg/tg) mutant mouse. Neuroscience 85:773-783, 1998.

113. Abbott LC, Bump M, Brandl A, De Laune S. Investigation of the role of the cerebellum in the myoclonic-like movement disorder exhibited by tottering mice. Mov Disord 15:53-59, 2000.

114. Campbell DB, North JB, Hess EJ. Tottering mouse motor dysfunction is abolished on the Purkinje cell degeneration (PCD) mutant background. Exp Neurol 160:268-278, 1999.

115. Pizoli CE, Jinnah HA, Billingsley ML, Hess EJ. Abnormal cerebellar signaling induces dystonia in mice. J Neurosci 22:78257833, 2002.

116. Eidelberg D, Moeller JR, Ishikawa T, Dhawan V, Spetsieris P, Przedborski S, et al. The metabolic topography of idiopathic torsion dystonia. Brain 118:1473-1484, 1995.

117. Eidelberg D, Moeller J, R., Antonini A, Kazumata K, Nakamura T, Dhawan V, et al. Functional brain networks in DYT1 dystonia. Ann Neurol 44:303-312, 1998.

118. Kluge A, Kettner B, Zschenderlein R, Sandrock D, Munz DL, Hesse $\mathrm{S}$, et al. Changes in perfusion pattern using ECD-SPECT indicate frontal lobe and cerebellar involvement in exercise-induced paroxysmal dystonia. Mov Disord 13:125-134, 1998.

119. Gernert M, Richter A, Loscher W. In vivo extracellular electrophysiology of pallidal neurons in dystonic and nondystonic hamsters. J Neurosci Res 57:894-905, 1999.

120. Brown A, Bernier G, Mathieu M, Rossant J, Kothary R. The mouse dystonia musculorum gene is a neural isoform of bullous pemphigoid antigen 1. Nat Genet 10:301-306, 1995.

121. Dalpe G, Leclerc N, Vallee A, Messer A, Mathieu M, De Repentigny $\mathrm{Y}$, et al. Dystonin is essential for maintaining neuronal cytoskeleton organization. Mol Cell Neurosci 10:243-257, 1998.

122. Messer A, Strominger NL. An allele of the mouse mutant dystonia musculorum exhibits lesions in red nucleus and striatum. Neuroscience 5:543-549, 1980.

123. Duchen LW, Strich SJ, Falconer DS. Clinical and pathological studies of an hereditary neuropathy in mice (dystonia musculorum). Brain 87:367-378, 1964.

124. Jinnah HA, Egami K, Rao L, Shin M, Kasim S, Hess EJ. Expression of c-fos in the brain after activation of L-type calcium channels. Dev Neurosci 25:403-411, 2003.

125. Jinnah HA, Sepkuty JP, Ho T, Yitta S, Drew T, Rothstein JD, et al. Calcium channel agonists and dystonia in the mouse. Mov Disord 15:542-551, 2000. 